\section{SINGIDUNUM \\ VERSITA}

SINGIDUNUM JOURNAL 2013, 10 (2): 40-52

ISSN 2217-8090

UDK 338.487:659.1(497.11)

DOI: $10.5937 /$ sjas $10-4327$

Original paper/Originalni naučni rad

\title{
PROPOSAL FOR SERBIAN TOURISM DESTINATIONS MARKETING CAMPAIGN
}

\author{
Ivan Paunovićc ${ }^{1, *}$ \\ ${ }^{1}$ Singidunum University, PhD student, \\ 32 Danijelova Street, Belgrade, Serbia
}

\begin{abstract}
:
Serbia is geographically located in Europe, which is why it faces stiff competition from other European destinations, but also from other destinations worldwide. In order to understand contemporary competitive environment, major trends have been identified at the global, regional and local level. The data from the analysis of Serbian summer season tourism market were used to create tourist profiles for 4 supply side regions (Domestic-Serbia; Western Balkans-Slovenia, Croatia, Bosnia, Montenegro, Kosovo and Macedonia; Central-Eastern Europe-Austria, Czech Republic, Slovakia, Poland, Hungary, Romania; Western Europe and the rest of the world), for 5 major Serbian destinations (Belgrade, Novi Sad, Niš, Zlatibor, Kopaonik) and for 7 types of tourists according to their core motivation for travelling (pleasure, fun \& entertainment, nature, culture, sport $\&$ adventure, health, and business). Based on the given tourist profiles, separate marketing campaign scenarios were created for each of the market segments.
\end{abstract}

\section{Key words:}

tourism marketing campaign, tourist profiles, destination marketing, market research, market segmentation.

\section{INTRODUCTION}

Europe, as a destination, continues to play a dominant role in global tourism. However, the growth of European destinations is lower than in developing countries (Unković, 2011). The average annual growth, on a global level, is projected to be $4 \%$, while in Europe it is expected to be around 2.6\% (World Tourism Organization, 2011). On the other hand, tourist arrivals in Serbia were expected to grow at an annual growth rate of approximately $25 \%$ during the period 2006-2015, according to the National Strategy for Tourism Development (Službeni glasnik Republike Srbije, 2006). In the period 2005-2011, the growth in arrivals was around $0.07 \%$ per annum (Republički zavod za statistiku Republike Srbije, 2013).

\section{Major Serbian tourism destinations and European market}

An important aspect of tourism destination marketing is the awareness of the neighboring destinations, since effective cross-border cooperation can be mutually beneficial. Stojkov and Nikolov emphasize the importance of cultural tourism in cross-border cooperation in the Balkans. The borders often changed in the past which has resulted in a rich mosaic of various potential cultural products (Stojkov and Nikolov, 2011). The formation of regional Destination Management Organizations (DMOs) is a prerequisite for the whole destination to be successful. The two strongest regional destination management organizations in Serbia are Western Serbia and Vojvodina. Western Serbia, 
including Zlatibor as the strongest Serbian destination, focuses on the creation of active holidays. As Plavša et al. notice, modern explorer-tourists seek active holiday. Zlatibor has a variety of natural resources, which can be developed into an interesting active holiday destination. (Plavša, Romelić and Vuksanović, 2009). Research conducted by Mulec concluded that Vojvodina is not an internationally recognizable destination. However, it plans to raise its profile on the international market through active marketing activities (Mulec, 2011).

The main competitors in the Serbian mountain tourism market are: Zlatibor and Western Serbia region, Kopaonik, and Stara Planina as a new destination. Kopaonik struggles to keep up with the competitors in the off-season. Bojović and Plavša report that there are around 7000 beds, and that the occupancy rate is about $16 \%$ throughout year. The main problem is the lack of activities, especially during the off-season. The possible solution proposed by the authors is networking with following spas located near Kopaonik: Vrnjačka Banja, Mataruška Banja, Bogutovačka Banja, Novopazarska Banja and Sijarinska Banja (Bojović and Plavša, 2011). This is consistent with the findings of Boga and Weiermair, who identified, on a large sample, $(\mathrm{N}=1607)$ a coherent value structure of health services offer in Alpine destinations. Their findings indicate that the health offer can be integrated into the broader concept of brand personality (Boga and Weiermair, 2011). Laesserer's insights from the Swiss health market show that major health travel activities include the following: relaxation, medium-warm water sports, as well as challenging sports activities. Health is also associated with mental regeneration. The age group dominating the health tourism market is baby-boomers, born between 1946 and 1964 . The health tourism facilities need to adjust the offer, place accent on the relaxation, beauty, wellness activities along with the occasional stimulating sport activities: hiking, biking and golfing (Laesser, 2011). Similarly, Mojić identified the importance of sport activities in Niška Banja, the famous spa located near the city of Niš The author conducted a complex multifactor assessment of resources in this spa, and concluded that its highest priority is the construction of the recreation center "Lozni Kamen". The construction of that center would expand sports activities offer in Niška Banja (Mojić, 2011). Contrary to these findings stands the analysis of the Finish market, conducted by Konu. The author identified the following 5 most popular health tourist activities: going to sauna, sleeping, taking a massage, going for walks and eating healthy food (Konu, 2010). The difference in findings is probably due to considerably different climate in Finland compared to Switzerland or Serbia. Regardless of the activities, Voigt et al. identified the primary motivators of wellness tourists in Australia: transcendence, physical health and appearance, escape and relaxation (Voigt, Brown and Howat, 2011).

Belgrade, as a tourism destination, is not competitive in terms of walking tours around the city compared to other major Serbian destinations. As Maksin noticed, natural heritage is not sufficiently included in the tourist offer of Belgrade, due to the undeveloped infrastructure around green areas. An important element in the city tourism offer are open spaces, because they act as a facilitator and integrate the tourism offer in all big cities around the world. Open areas enhance urban identity and landscape in the modern city (Maksin, 2011). Economic activities in Belgrade have in many areas degraded the environment. The most notable example is Belgrade harbor freight transport that goes through the center, along the Sava River. Cirić noticed that tourists avoid destinations with polluted environment (Ćirić, 2011). The major challenges that tourism industry faces, identified by UN Environment Programme include the following: green house gases emissions and energy, water consumption, waste management, biological diversity endangerment, effective cultural heritage management (United Nations Environment Programme, 2011). Traditional economic theory is moving from creating wealth as an end-goal towards modern holistic economic approach that takes into account human and environmental needs (World Tourism Organization, 2011). The UNWTO Handbook on Tourism Product Development presents the case of Guggenheim Museum Bilbao as an illustration of successful revitalization of post-industrial city, which can serve as a good example for Belgrade tourism development. Guggenheim Bilbao achieved dramatic effects in the local community, for a project worth 100 million US dollars. It was a part of the Bilbao Metropolitan Revitalization Plan aimed at redeveloping the city and diversifying local economy. The city changed in the sense that parks, cycle lanes and riverside cafes replaced the post-industrial environment. The museum hosts around million visitors a year and construction costs were covered three years following the day of the construction (World Tourism Organization and European Travel Commission, 2011). 
Serbian tourism can benefit from creating Tito's tourism products since there are two important landmarks from Tito's life on the Serbian territory: The Republic of Užice (the first Nazi-free territory during WWII, and nucleus of the communist state), and Tito's grave in Belgrade (The House of Flowers). Cultural products focusing on the communist era with Tito as the most recognizable brand can be marketed to the global markets. The potentials of important landmarks from Tito's personal history and communist party history are not managed properly. Apart from the historical facts, there is a number of legends which give communist brands strong word-of-mouth promotion (Ivanović and Milićević, 2009). Balažič also agrees that the memory of communism is still alive in Slovenia and it is a popular theme in every day chit -chats and reflections in bars and cafes. Communism is still alive in Slovenia through singing of the partisan songs, continuation of several decades old memorial celebrations, large signs with Tito's name put on the hillsides (similar to the famous Hollywood sign), and opening of the bars with Tito's theme (Balažič, 2011). All sources agree on the fact that Tito is the most recognizable brand from the communist era, and that the communist legacy is still present in many facets of the everyday life.

The Danube is undoubtedly the most important tourist resource in Serbia, connecting it with other 10 European countries-destinations. Tourism Development Strategy of the Republic of Serbia recognized the importance of the Danube in two segments: 1 . Locations along the Danube shores are designated for future investments, 2 . The Danube gives Serbian destinations international recognition, and hence the slogan for promoting Serbia is: "Where Danube meets Balkans" (Službeni glasnik Republike Srbije, 2006). One of the projects realized as part of the Tourism Development Strategy of the Republic of Serbia is bicycle route through Serbia. It is part of EuroVelo route 6, which is $3,653 \mathrm{~km}$ long, and goes from the Atlantic Ocean to the Black Sea (Eurovelo 6, 2013). By indicating the importance of this route for Serbian tourism, Matijašević states that there were 5,722 foreign cycle tourists in the checkpoint Lepenski Vir, during the year 2009. They come from Germany, Austria and France and are mostly pensioners and students. Tour operators from Germany, Austria and Holland started offering this route in 2008. By 2009, this product became well established on the European tourism market (Matijašević, 2009).
Štetić and Šimičević found that around 43\% of the population in Serbia lives in rural areas, on the territory that covers around $90 \%$ of the whole country. This area contains 1300 protected natural objects and is very rich in flora and fauna (Štetić and Šimičević, 2008). The EUROBAROMETER research results from 1997 indicate that the smaller countries in Central Eastern Europe have a tendency of being visited mostly for cultural reasons. On the other hand, those with more diversified tourism product portfolio attract rural and beach tourism (World Tourism Organization and European Travel Commission, 2005). Rural tourism is suitable for diversification of rural economies (Zrilić, 2011). It is a tool used by the countries to achieve different goals through tourism: economic sustainability, sociocultural sustainability, and environmental sustainability. Many countries in this part of the world are competing in the rural tourism market: Romania, Bulgaria, Hungary, Czech Republic, Slovakia, and Slovenia (UN Joint Programme "Sustainable Tourism for Rural Development”, 2011). Kosovo does not have the strategy of rural development, but is in contrast using bottom-up approach. Novo Brdo (Kosovo) developed the first strategy of rural development, as the destination with considerable potential in the rural tourism market (Municipal assembly of Novobërdë, 2008). As Vasilevska notices, important issues in the strategies of rural development are that they are long-lasting and have a system approach. Also, they are very rarely successful in the areas with negative demographic trends. Rural tourism facilitates social and cultural development, at the same time preserving traditional crafts, food, and spaces (Vasilevska, 2010). The conservation of architecture is an activity that bears in mind two criteria: artistic value and ethnological value (Vasilevska, 2011). Research conducted by Medica et al. reported that the preservation of traditional architecture at farms in Istria (Croatia) gave considerable results and had an overall positive influence on the tourism offer (Medica, Ružić and Ružić, 2010). Alternative forms of tourism are entering the mainstream tourism market, but are not likely to become the leading segments of the market. As López-Guzmán et al. found on the case of community tourism in El Salvador, the local communities lack the resources to produce high-quality tourism products. However, it also indicates that there are alternatives to destination development, and there is no single solution for all destinations (LópezGuzmán, Sánchez-Cañizares and Pavón, 2011). 


\section{Events as an important part of Serbian tourism}

Events range from small-scale events to large ones, and can encompass sport, music, culture, business, science, etc. Stamenković et al.conducted research on one of the most famous Serbian music festival brands: the traditional trumpet festival in Guča. They found that in assessing the Guča as Serbian brand, younger interviewers up to 20 years old, gave statistically significantly lower marks than any other group. This is probably the market segment where other music brands, such as Exit in Novi Sad, with popular music are better positioned (Stamenković et al., 2013). Guča is a fairly strong brand as a music festival, but is not as strong as a tourism brand because it lacks basic tourism infrastructure and services. Radivojević and Paunović found in their research of Guča and Lučani accommodation, that $2 / 3$ of households do not want to accept visitors during the whole year. There are also $83.87 \%$ of the households that do not want to register officially as accommodation. This research gives an insight into the accommodation market which cannot be researched only through official statistics. According to the research, only $16.13 \%$ of Dragačevo and Lučani households are willing to register and categorize their accommodation (Radivojević and Paunović, 2011).

In recent years, Serbia hosted one mega event: Universiade 2009 in Belgrade. An important segment of this mega event are volunteers. Nasaar and Talaat researched the young volunteers in special events and their motivations. They discovered that different mixture of motivators (desire to meet people, gaining new experience, self-esteem, sense of affiliation, escape from routine) can be observed in volunteers in different kinds of events: sport, cultural, festival, charity, conventions. This means that students are exhibiting their personality through the choice of event. They are volunteering in order to achieve inner fulfillment through contributing to community, at the same time developing skills necessary for the job market. Volunteering is a process that provides benefits to the volunteers themselves, as well as to the organizations they are volunteering for, and society as a whole, through enhanced social cohesion. Authors identified the following key elements in volunteer management: planning, expense management, quality management, and effectiveness (Nasaar and Talaat, 2009). Management theory suggests that there are five elements in management process: planning, organizing, leadership, and control (Erić, 2000). Musgrave, on the other hand, proposes implementing sustainability and quality management as integral parts of event management (Musgrave, 2011). Jovičić emphasizes that management of environmental issues in tourism, as part of quality management initiatives, is a recent development. On the other hand, there are notable examples of cases where these systems gave considerable results: ECOTOUR in Balearic Islands, TUI-Umwelt-Netzwerk, and company Center Parcs (Jovičić, 2009).

\section{EXPERIMENTAL RESEARCH}

\section{The Subject of the Research}

The subject of the research was to analyze Serbian tourism market and segment it, in order to serve it more effectively and efficiently.

\section{Delimitations}

The survey was conducted only during summer season, so the data should be approached with caution. However, the samples were weighted according to the official statistics in order to gain more reliable data.

\section{Research Goal}

The research was designed with the aim to provide the answer to three research questions:

1. RQ1: In which activities do tourists most frequently engage in Serbia during summer season?

2. RQ2: Which sources of information do tourists use about the summer season travel in Serbia?

3. RQ3: What are the major characteristics of each market segment, destination and motivation for travel at the Serbian summer season tourism market?

\section{Research Design}

The data was collected through conducting Serbia Guest Survey 2011. The survey has been conducted as a component of the EU funded project: "Support to implementation of the National Strategy for Tourism" 07SER01/23/11. The data used in 
this paper represent the synthesis of a large number of statistical analyses performed during the project. The objectives of the survey were to assess tourist profiles, core motives for travelling, booking habits, expenditures, satisfaction and image perception of Serbia.

The questionnaire was filled in by tourists themselves, with the instruction and assistance of the interviewers. The interviewers were positioned at central locations of each tourist destination. The target group were domestic and foreign tourists in Serbia, aged over 14 years, staying overnight, but no longer than 30 days (holiday trip), or 90 days (business trip). The database was weighted by overnight stays and country cluster (Western Europe and the rest of the world, CEE, Western Balkans, Serbia) based on the official statistics.

Total sample included 1500 respondents at the following locations in Serbia: Belgrade, Novi Sad, Zlatibor, Guča, Kopaonik, Fruška Gora, Zasavica,
Vrdnik, Erdevik, Sremska Mitrovica, Divčibare, Valjevo, Banja Vrujci, Sokobanja, Vrnjačka Banja Banja Koviljača, Niška Banja, Niš, Subotica, Vršac, Palić Lake, Bela Crkva Lakes, Silver Lake, Ečka Skorenovac.

The fieldwork was done during the period: July 11, 2011 - September 5, 2011.

The author of the study was engaged on the position of Office Manager on the project, which was implemented by consortium led by public consulting company HD-European Consulting Group.

As presented in the Table 1, the demand side of the market consists of the following segments: domestic, Western Europe and the rest of the world, Central-Eastern Europe, Western Balkans. Supply side of the market includes the following major destinations: Belgrade, Novi Sad, Niš, Kopaonik, Zlatibor and Western Serbia. Core motivations for travelling include the following: Pleasure, Fun \& Entertainment, Nature, Culture, Sport \& Adventure, Health, and Business.

\begin{tabular}{ccc}
\hline Regions of origin & Primary motivation for travel & Major destinations \\
\hline Domestic & Pleasure & Belgrade \\
\hline Western Balkans & Fun and entertainment & Novi Sad \\
\hline Central Eastern Europe & Nature & Niš \\
\hline Western Europe and the rest of the world & Culture & Klatibor and Western Serbia \\
\hline
\end{tabular}

Table 1: Serbian summer season tourism market segments

\section{REPORT OF FINDINGS}

\section{Report of findings for tourism activities during the summer season}

As presented in the Graph 1 and Graph 2, the most frequent activities of tourists in Serbia during the summer season include the following: going for walks (66.7\%), hiking (sport activities - 62.5\%), sightseeing (55.7\%), swimming/bathing (sport activities - 21.8\%), bars/discos/nightlife (21.5\%), enjoying typical food and beverages of the region(20.1\%), visiting natural attractions (18.2\%), visiting attractions in general (17.4\%), festivals/events (17.4\%), going to restaurants (17.2\%), climbing (sport activities $-12.3 \%)$, excursions away from the holiday destination (11\%) and shopping-not daily needs (10.3\%).

\section{Report of findings for tourist source of information about the destination during summer season}

As presented in the Graph 3, the most frequently used sources of information about the destinations in Serbia include the following: friends/relatives (53.9\%), Internet-in general (22.5\%), reports and advertising in the media (8\%), and Internet travel websites and booking platforms (5.5\%).

\section{Report of findings for tourist profiles on the demand side of the market (regions of origin)}

A typical domestic tourist is about 36 years old, spends around 26 euro daily, and stays for about 7 days at the destination. The favorite destinations 
of the domestic tourist are Western Serbia/Zlatibor, Kopaonik and Belgrade. Such tourist travels for nature and fun \& entertainment and stays in free accommodation, private lodgings, or hotels. This type of tourist likes getting information from the reports or advertising in the media, usually visits natural attractions and goes climbing. His/her main mean of transport is a car or a bus.

A typical tourist from Western Europe and the rest of the world is around 33 years old, spends about 109 euro daily, and stays for about 7 days at the destination. The favorite destinations of such tourist are Belgrade and Novi Sad and the main motivations for travelling are fun \& entertainment and culture. He/she usually stays in hotels, hostels or free accommodation, often travels by a plain or a train and likes getting information from travel literature/travel guides, Internet travel websites and booking platforms, and social websites (e.g. Facebook). This type of tourist usually goes to bars/discos/nightlife, restaurants, visits natural attractions and museums/exhibitions.

Central Eastern European tourist is around 34 years old, spends approximately 59 euro daily, and stays for about 6 days at the destination. The favorite destinations of such tourist are Belgrade and Zlatibor. $\mathrm{He} /$ she travels for fun \& entertainment and culture, stays in hotels, private lodgings or hostels. Central Eastern European tourist often travels by a plane, train or hitch-hikes and prefers getting information from the Internet travel websites, booking platforms, social websites (e.g. Facebook), travel agents, or travel literature/travel guides. He/she usually goes to excursions away from the holiday destination, restaurants, and museum/exhibitions.

Western Balkans tourist is around 38 years old, spends nearly 50 euro per day, and stays for about 6 days at the destination. The favourite destinations of such tourist are Belgrade, Novi Sad and Zlatibor. This type of tourist travels for fun \& entertainment and business and stays in free accommodation, hotels, or private lodgings. $\mathrm{He} /$ she often travels by train and prefers getting information from the reports and advertisements in the media. He/she usually visits natural attractions, goes to restaurants and shopping (not daily needs).

\section{Report of findings on profiles on supply side of the market (destinations)}

Belgrade tourist is around 33 years old, spends approximately 65 euro daily, and stays for about 6 days at the destination. He/she often comes from Western Europe and the rest of the world, Western Balkans or Central Eastern Europe. He/she travels for fun \& entertainment, business or culture, stays in hostels, hotels, or private lodgings, travels alone, with friends/colleagues, or with partner/spouse. Such tourist often travels by train or a plain, likes getting information from the reports or advertising in the media, Internet travel websites/booking platforms, or travel literature/travel guides. Belgrade tourist usually goes to festivals/events, swimming/bathing, restaurants, enjoys typical food and drinks of the region, visits attractions, or goes shopping (not daily needs).

Novi Sad tourist is around 29 years old, spends about 33 euro daily, and stays for about 7 days at the destination. $\mathrm{He} / \mathrm{she}$ is often from Western Europe and the rest of the world or Western Balkans, travels for fun \& entertainment, business, nature or culture, stays in hostel, hotel, or holiday apartment, travels with friends/colleagues, alone or with partner/ spouse. Moreover, he/she often travels by train or a plain, likes getting information from travel literature/travel guides, Internet travel websites/booking platforms, or social websites (e.g. Facebook). Such tourist usually visits attractions, enjoys typical food and drinks of the region, goes shopping (not daily needs), goes to restaurants, visits natural attractions, does excursions away from the holiday destination.

Niš tourist is around 36 years old, spends about 30 euro daily, stays for about 7 days at the destination, and comes from Serbia. The main motive to travel to Niš is fun \& entertainment, business or health. This type of tourist stays in hotels or private lodgings travels with a partner/spouse, alone, with friends/colleagues, or with children under 14 . He / she travels only by a car or a bus, likes getting information from social websites (e.g. Facebook). He/ she usually goes to restaurants, enjoys typical food and beverages of the region, goes to festivals/events, visits attractions, goes to excursions away from the holiday destination and visits natural attractions.

Kopaonik tourist is around 40 years old, spends about 39 euro daily, stays for about 8 days at the destination, and comes from Serbia. The main motive for travelling to Kopaonik is for nature, business or sport \& adventure. He/she stays in a hotel, company owned resort or hostel, travels with partner/spouse, children under 14, alone, or with friends/colleagues. This type of tourist travels by a car or a bus, and sometimes by a plane, likes getting information from the reports and advertising in the media, Internet 
travel websites and booking platforms, or through travel agent. He/she usually engages in climbing, visits natural attractions, does mountaineering (highly active mountain tours), jogging/running, goes to sports events, or does horse riding.

Zlatibor and Western Serbia tourist is around 35 years old, spends approximately 32 euro daily, stays for about 7 days at the destination, and comes from Serbia. The main motive to travel is fun \& entertainment, nature, health or culture. Such tourist stays in a private lodging, hotel, campsite or holiday apartment, travels with partner/spouse, friends/colleagues or children under 14 . He/she travels only by a car or a bus, prefers getting information from reports and advertisements in the media, Internet travel websites and booking platforms, or travel literature/travel guides. He/she usually enjoys food and beverages typical of the region, visits natural attractions, festivals/events, and attractions in general, does climbing and goes to restaurants.

\section{Report of findings on profiles by the core motivation for travelling}

Pleasure tourist is around 37 years old, spends approximately 33 euro daily, and stays for about 7 days at the destination. Favorite destinations of such tourists are Western Serbia/Zlatibor, Belgrade, Kopaonik, and Fruška Gora. This type of tourist is often from Western Balkans and stays in private lodgings or hotels, travels with partner/spouse, children under 14, alone or with friends/colleagues. The main mean of travel is a car or a bus. He/she likes getting information from the reports or advertisements in the media, usually goes swimming/bathing, visits attractions and especially natural attractions, enjoys typical food and drinks of the region.

Fun \& Entertainment tourist is around 29 years old, spends approximately 43 euro daily and stays for about 5 days at the destination. Favorite destinations of such tourist are Belgrade, Western Serbia/Zlatibor, and Niš. Fun \& entertainment tourist often comes from Western Europe and the rest of the world or from Central Eastern Europe and stays in free accommodation or campsites. $\mathrm{He} / \mathrm{she}$ travels with friends/colleagues, alone or with partner/spouse, uses train pretty often, likes reports and advertisements in the media, going to bars/ discos/nightlife, festivals/events, and swimming/ bathing.

Nature tourist is around 39 years old, spends approximately 28 euro daily and stays for about 7 days at the destination. Favourite destinations of such tourist are Kopaonik, Divčibare/Valjevo, West Serbia/Zlatibor, and Novi Sad. He/she prefers staying in private lodgings or hotels, travels with partner/ spouse, children under 14, or friends/colleagues, uses a mixture of sources for obtaining information about the destination, visits natural attractions, enjoys typical food and drinks of the region, and likes climbing and swimming/bathing.

Cultural tourist is around 38 years old, spends about 50 euro daily, and stays for about 5 days at the destination. His/her favorite destinations are Belgrade, Vršac/South Banat, West Serbia/Zlatibor, and Novi Sad. Such tourist often comes from Western Europe or elsewhere from the world or Central Eastern Europe, usually stays in private lodgings and hostels, and travels with partner/spouse, friends/ colleagues, or alone. He/she often uses a plain or a train, and also likes hitch-hiking. This type of tourist likes getting information from travel literature/ travel guides, visits attractions, enjoys typical food and drinks from the region, and goes to museums and exhibitions. Cultural tourist is the second least loyal type of tourist to Serbia as a destination.

Sport \& adventure tourist is around 27 years old, spends about 36 euro daily, and stays for about 10 days at the destination. Favorite destinations of such tourist are Kopaonik and Fruška gora. This type of tourist often comes from Central Eastern Europe, or Western Europe and the rest of the world, usually stays at the hotel or campsite, and travels with friends/colleagues, organized travel groups, or alone. $\mathrm{He} /$ she likes taking a train, uses social websites in order to obtain information about the destination, and books accommodation primarily through travel agent/tour operator. He/she likes sports events, jogging/running, cycling (paved cycle routes), and going to bars/discos/nightlife. Sport \& adventure tourist is the second most loyal type of tourist to Serbia as a destination.

Health tourist is around 46 years old, spends approximately 24 euro daily, and stays at the destination for about 10 days. His/her favourite destinations include Divčibare/Valjevo, Western Serbia/Zlatibor, Kopaonik, Niš, and Stara Planina. He/she usually comes from Serbia, and stays in private lodgings or in hotels, travels with partner/spouse, children under 14, or alone, uses only car and a bus, and gets information from various sources. Such tourist likes using health facilities, swimming/bathing, visiting natural attractions, or climbing. Health tourist is the most loyal tourist to Serbia as a destination. 
Business tourist is approximately 37 years old, spends around 62 euro daily, and stays for about 7 days at the destination. His/her favorite destinations are Belgrade, Kopaonik, Palić and Niš. He/she often comes from Western Balkans or Western Europe and the rest of the world, usually stays at the hotel, and travels either with friends/colleagues or alone. This type of tourist often uses plane and different sources to obtain information, likes going to restaurants, bars/discos/nightlife, enjoys typical food and drinks of the region, and likes shopping (not daily needs). Business tourist is the least loyal type of tourist to Serbia as a destination.

\section{ANALYSIS OF FINDINGS}

\section{Analysis of findings for tourism activities in the summer season}

The six most important components in the Serbian summer tourism value chain are as follows (see Graph 1 and Graph 2): sightseeing related servicestransportation etc. (55.7\%) swimming/bathing related services $(21.8 \%)$, nightlife $(21.5 \%)$, catering industry $(20.1 \%)$, natural attractions $(18.2 \%)$ and events (17.4\%).

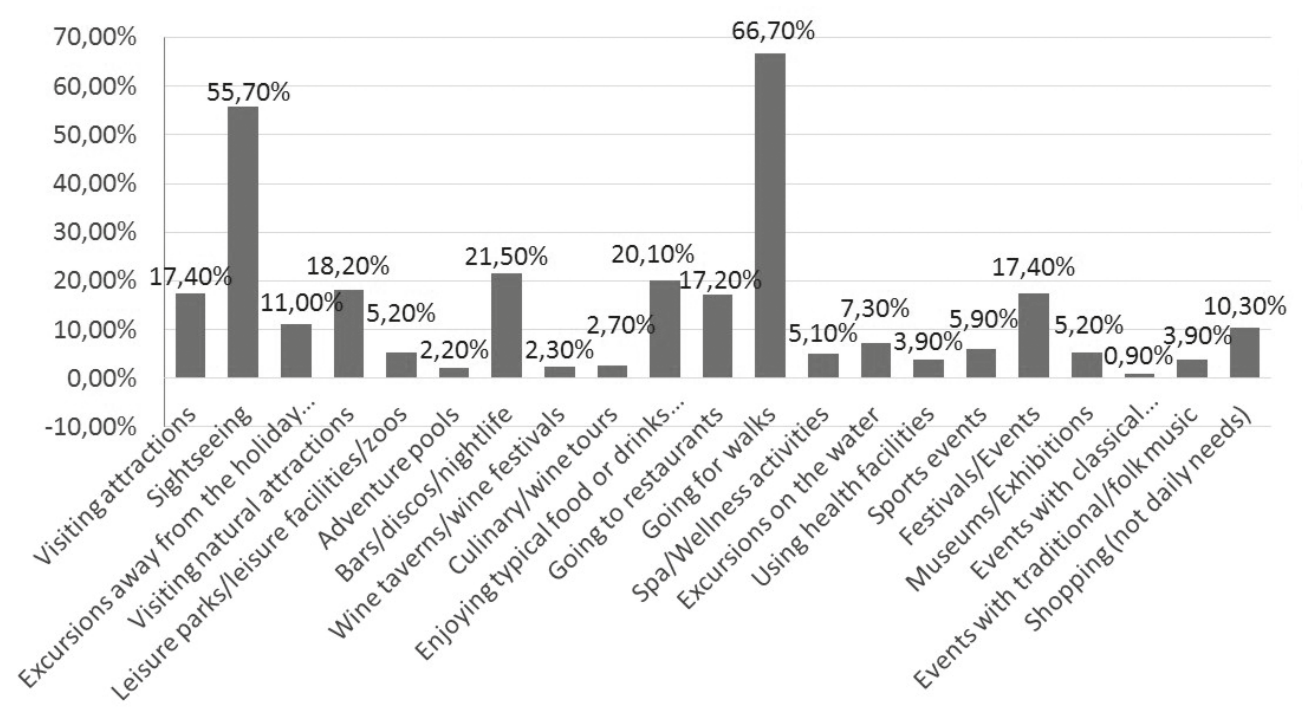

Graph 1: General tourist activities in Serbia during summer season

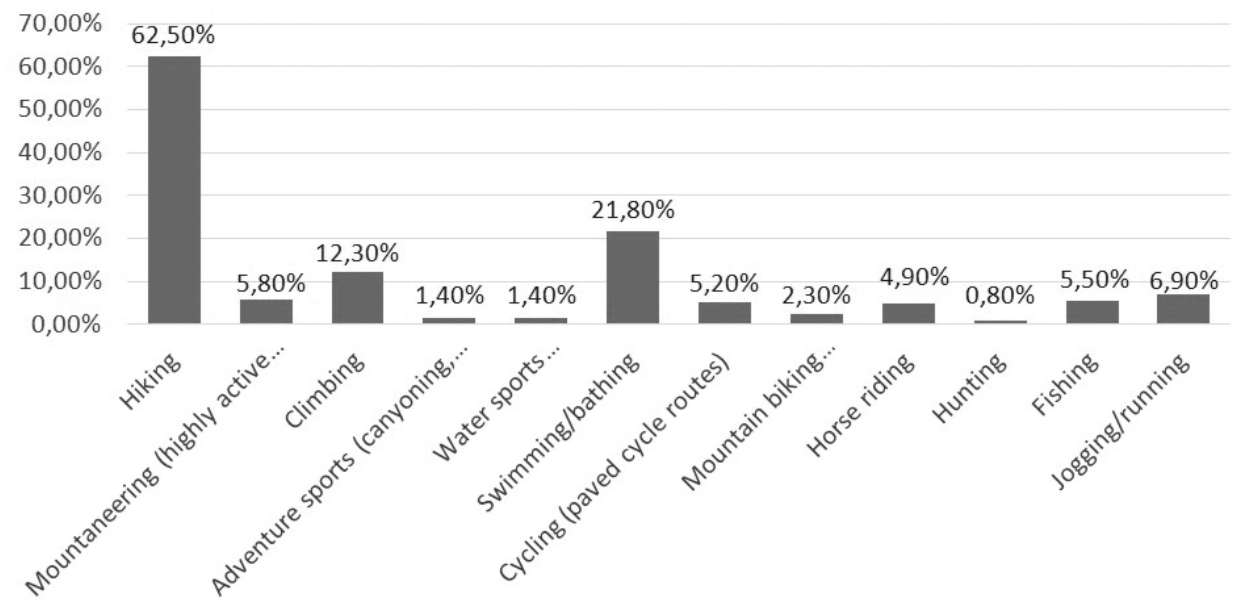




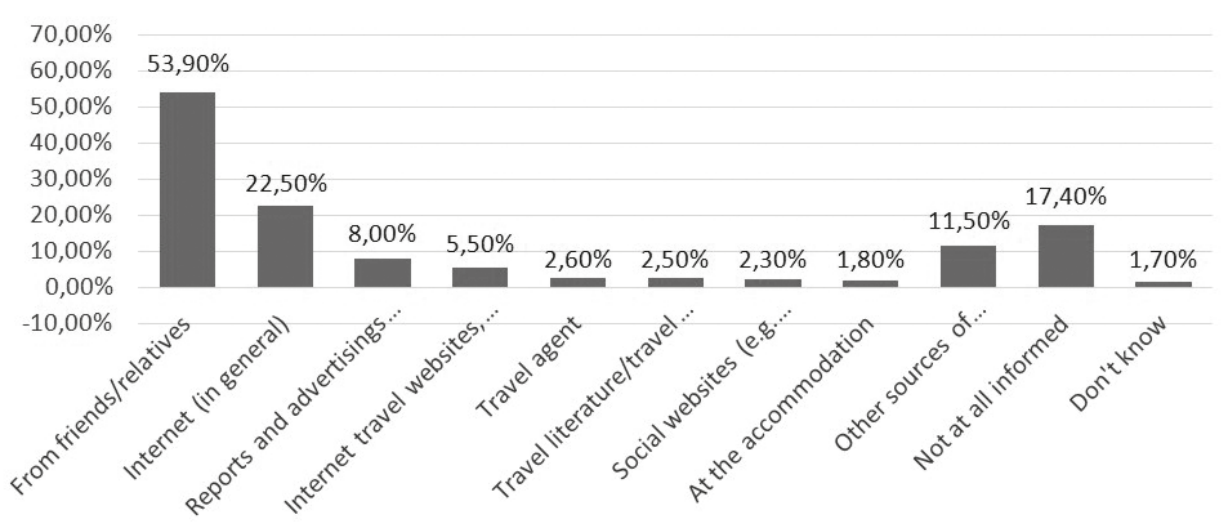

Graph 3: Tourist information sources about Serbian destinations during summer season

\section{Analysis of findings for tourist source of information about the destination during summer season}

The Internet has become the primary media used as a source of information regarding Serbian tourism destinations (see Graph 3). Namely, 22.5\% of tourists use the Internet in general to obtain information, while only $8 \%$ use reports and advertisements in the classic media. Friends and relatives remain the primary source of information with $53.9 \%$ which shows that the power of the reference groups is still the single most important factor in the process of getting information about destinations.

\section{Analysis of findings for demand side of the market (regions of origin)}

Tourism marketing campaign targeting Domestic tourists should target families with small children or teenagers involved in the activities such as visiting natural attractions or swimming/bathing. The primary motivation for travelling is nature, but also fun \& entertainment. The campaign should use the reports and advertisements in the media, as well as hotel media. The message should encourage identification with Serbia and emphasize uniqueness of Serbia as a destination.

Tourism marketing campaign targeting Western Europe and the rest of the world tourists should target groups of people in their late twenties or early thirties or young couples with no children involved in the activities such as going to bars/discos/nightlife, restaurants, visiting natural attractions, going to museums/exhibitions. Apart from fun \& entertainment, their main motivation for travelling is culture. The campaign should use travel literature/ travel guides, Internet travel websites and booking platforms, social websites (e.g. Facebook), as well as the media in the airport/airplane setting, as well as in trains/train stations and hotels. The message should develop trust and emphasize value proposition over destination itself.

Tourism marketing campaign targeting Central Eastern European tourists should target groups of people in their thirties or young couples with no or small children involved in the following activities: excursions away from the holiday destination, going to restaurants, museum/exhibitions. Apart from fun \& entertainment, their primary motivation for travelling is culture. The campaign should use the Internet travel websites/booking platforms and travel agent/tour operator media, as well as media in the airport/airplane setting, trains/train stations, hotels, hostels and hitch-hiking community media. The message should develop trust and emphasize value proposition over destination itself.

Tourism marketing campaign targeting Western Balkan tourists should target couples in their late thirties and early forties with primary school children, or individualistic person involved in the following activities: visiting natural attractions, going to restaurants, and shopping. Apart from fun \& entertainment, their primary motivation for travelling is business. The campaign should use the reports and advertisements in the media, but also hotel media and media in trains/train stations for conveying the message.

\section{Analysis of findings for supply side of the market (destinations)}

Tourism marketing campaign targeting Belgrade tourists should target individualistic person or a couple without children/group of people in late twenties 
or early thirties involved in the activities which include a wide range of activities such as visiting festivals/events, swimming/bathing, going to restaurants, visiting attractions (including museums/exhibitions) or shopping (not daily needs). It should portray persons that embrace the values of the global consumer culture. The campaign should use the reports and advertisements in the media as well as the Internet travel websites/booking platforms and travel literature/travel guides, as well as media in plane/airport setting, trains/train stations and in hotels and hostels. The message should encourage identification with Belgrade and emphasize uniqueness of Belgrade as a destination.

Tourism marketing campaign targeting Novi Sad tourists should target groups of young people in their twenties involved in the following activities: visiting attractions in general and more specifically natural attractions, enjoying typical food and beverages of the region, and shopping (not daily needs). It should portray persons that embrace the values of the global consumer culture. The campaign should focus on travel literature/travel guides, Internet travel websites and booking platforms, social websites (e.g. Facebook), as well as media in the plane/airport setting, trains/train stations and in hotels and hostels.

Tourism marketing campaign targeting Niš tourists should target families with primary school children or individuals and groups of people in their thirties and forties involved in the activities which include the following: going to restaurants, enjoying typical food and drinks from the region, visiting festivals/events and attractions. It should portray persons that embrace the values of the Serbian/Balkan culture. The campaign should focus on the Internet in general as well as social networks (e.g. Facebook), and hotel media. The message should build trust and emphasize value proposition over destination itself.

Tourism marketing campaign targeting Kopaonik tourists should target families with school children or partners in their forties engaged in the following activities: climbing, visiting natural attractions, mountaineering (highly active mountain tours), jogging/ running, sports events, and horse riding. It should portray persons that embrace the values of the Serbian/Balkan culture. The campaign should use the reports and advertisements in media, Internet travel websites and booking platforms and travel literature/ travel guides, as well as the media in the airport/ airplane setting, in hotels and hostels. The message should build trust and emphasize value proposition over destination itself.
Tourism marketing campaign targeting Zlatibor and Western Serbia tourists should target families with primary school children or groups of people in their thirties and forties involved in the following activities: enjoying typical food and drinks of the region, visiting natural and other attractions, festivals/events, climbing, and going to restaurants. It should portray persons that embrace the values of the Serbian/Balkan culture. The campaign should use the reports and advertising in the media, Internet travel websites and booking platforms, travel literature/travel guides, as well as the media in hotels and campsite community media. The message should encourage identification with Zlatibor and emphasize uniqueness of Zlatibor as a destination.

\section{Analysis of findings for core motivation for travelling}

Tourism marketing campaign targeting Pleasure tourists should target families with small children (with parents in focus) involved in the activities such as swimming/bathing, visiting natural and other attractions, enjoying local dishes and beverages at one of the following destinations: Western Serbia/Zlatibor, Belgrade, Kopaonik or Fruška Gora. It should use the Internet campaigns and reports and advertisements in the media.

Tourism marketing campaign targeting fun and entertainment tourists should target young groups of people or young individuals in their twenties involved in the activities which include bars/discos/ nightlife, festivals/events, swimming/bathing at one of the following destinations: Belgrade, West Serbia/ Zlatibor or Niš. It should use the Internet campaigns, reports and advertisements in the media and on the trains/train stations, as well as camping community media in order to convey the message.

Tourism marketing campaign targeting nature tourists should target families with primary school aged children involved in the activities such as visiting natural attractions, enjoying typical food and beverages of the region, climbing, and swimming/bathing at one of the following destinations: Kopaonik, Divčibare/Valjevo, Western Serbia/Zlatibor or Novi Sad. It should focus only on the Internet campaigns.

Tourism marketing campaign targeting cultural tourists should target couples without children or individualistic person in thirties or early forties involved in the activities which include attractions, galleries, museums, restaurants, local dishes and 
drinks at one of the following destinations: Belgrade, Vršac/South Banat, Western Serbia/Zlatibor, Novi Sad. It should use the Internet campaigns, media in plane/airport setting or in private lodgings/ hostels, as well as travel guides/travel literature, and media in the hitch-hiking community. The message should include, if appropriate, information about booking through local/regional tourism office. The message should develop trust and emphasize value proposition over destination itself.

Tourism marketing campaign targeting sport \& adventure tourists should target young groups of people in their twenties involved in the activities which include sport events, sport equipment, cycling, and bars/discos/nightlife at one of the following destinations: Kopaonik, Fruška Gora. It should use the Internet campaigns, especially social media (e.g. Facebook), travel agents/tour operator's brochures, as well as camping community media in order to convey the message. The message should encourage identification with Serbia and emphasize uniqueness of Serbia as a destination.

Tourism marketing campaign targeting health tourists should target a couple in their fifties with grandchildren involved in activities which include using health facilities, swimming/bathing, natural attractions or climbing at one of the following destinations: Divčibare/Valjevo, Western Serbia/Zlatibor, Kopaonik, Niš, Stara Planina. It should use only the Internet campaigns in order to convey the message. The message should encourage identification and pride with Serbia. It should also emphasize the attachment to Serbia as a destination on a personal level.

Tourism marketing campaign targeting Business tourists should target individualistic person in thirties or forties (possibly with colleagues) involved in the activities which include restaurants, bars/discos/nightlife, local cuisine and beverages as well as shopping activities at one of the following destinations: Belgrade, Kopaonik, Palić, Niš. It should use the Internet campaigns, other media in plane/airport setting, or hotels in order to convey the message. The message should develop trust and emphasize value proposition over destination itself.

\section{CONCLUSIONS AND RECOMMENDATIONS}

Cooper emphasized that the market demand is constantly shifting and new destinations are emerging on the global market. The destination of the future will give way to value and visitor experience, in contrast to the old paradigm of concentrating on the volume (Cooper et al., 2008).

Destinations can vary in terms of natural beauty, and the number of historical events that happened in the region (Biederman, 2008). However, successful tourism destination rarely develops by accident. It is a product of careful integral planning and represents an integrated area that includes accommodation, attractions, local community and transportation (Y. Gee and Fayos-Sola, 1997). Therefore, it is important to understand how tourists obtain information about the destination, as well as in which activities they engage within the destination itself. Only then can a successful marketing campaign be created and communicated to the market.

The most suitable media for communicating messages to Serbian summer season general market is the Internet, which has become the primary source of information concerning Serbian tourism destinations. As regards the tourist products which Serbia offers to summer season general market, the most important are sightseeing related services (transportation, etc.), swimming/bathing related services, and nightlife, catering industry, natural attractions and events. On the other hand, Serbian summer season tourism market is large enough to be meaningfully segmented. In this way, it can be served better, by creating and communicating various value propositions for each market segment.

\section{REFERENCES}

Balažič, G. (2011). Marshaling Tito: A Plan for Socialist Cultural Heritage Tourism in Slovenia. American Geographical Society's. Focus on Geography, 54(3), 103110. DOI: 10.1111/j.1949-8535.2011.00031.x.

Biederman, P.S. (2008). Travel and Tourism: An Industry Primer. Upper Saddle River, N.J: Pearson Prentice Hall.

Boga, T.C., \& Weiermair, K. (2011). Branding new services in health tourism. Tourism Review, 66(1/2), 90-106.

Bojović, G., \& Plavša, J. (2011). Swot Analysis of Tourism on Kopaonik and the Spas of its Piedmont. Turizam,15(3), 109-118.

Cooper, C., Fletcher, J., Fyall, A., Gilbert, D., \& Wanhill, S. (2008). Tourism Principles and Practice. Harlow, England: Pearson Education Limited.

Ćirić, N. (2011). Marketing and its Importance in Preserving the Environment and Development of Sustainable Tourism. Sustainable Development as Precondition for Competitiveness in Tourism (pp. 159-169). Belgrade: Belgrade Chamber of Commerce. 
Erić, D. (2000). Uvod u menadžment. Beograd: Ekonomski fakultet. (in Serbian)

Eurovelo 6. (2013). What's Eurovelo 6? Retrieved April 8, 2013, from http://en.eurovelo6.org/rubriques/gauche/ whats-ev6

Ivanović, M., \& Milićević, B. (2009). Some Challenges of Creating a New Brand of Serbian Tourism: Case Study - The Republic of Užice. Turizam, 13(1),17-27.

Jovičić, D. (2009). Eco-management systems and tourism. Regional cooperation in tourism development (pp. 1125). Belgrade: Belgrade Chamber of Commerce.

Konu, H. (2010). Identifying potential wellbeing tourism segments in Finland. Tourism Review, 65(2), 41-51.

Laesser, C. (2011). Health travel motivation and activities: insights from a mature market - Switzerland. Tourism Review, 66(1/2), 83-89.

López-Guzmán, T., Sánchez-Cañizares, S., \& Pavón, V. (2011) Community-based tourism in developing countries: A case study. Tourismos: An International Multidisciplinary Journal of Tourism, 6(1), 69-84.

Maksin, M. (2011). Sustainability of development of tourist destination Belgrade. Regional development in tourism development-sustainable development as a prerequisite of competitiveness in tourism (pp. 141-157). Belgrade: Belgrade Chamber of Commerce.

Matijašević, N. (2009). Measures for support to tourism development along the Danube river. Regional cooperation in tourism development (pp. 27-33). Belgrade: Belgrade Chamer of Commerce.

Medica, I., Ružić, P., \& Ružić, T. (2010). Architecture as a Tool for Branding in Rural Istrian Tourism Destination. Turizam, 14(2),78-86.

Mojić, J. (2011). Valuation of Tourist Potential Spa of Niš (Niška Banja) Area (South-east Serbia). Turizam, 15(3), 95-108.

Mulec, I. (2011). Image and Recognizability of Vojvodina as Potentiall tourist Destination in the Eyes of Foreign Tour-Operators. Cooperation In Tourism Development-Sustainable Development as Precondition for Tourism Competitiveness (pp. 121-130). Belgrade: Belgrade Chamber of Commerce.

Municipal assembly of Novobërdë. (2008). Rural Tourism Development Strategy in the Municipality of Novobërdë 2008-2015. Prishtina: CARE International Kosovo, ICCED Prishtinë.

Musgrave, J. (2011). Moving towards responsible events management. Worldwide Hospitality and Tourism Themes, 3(3), 258-274.

Nasaar, N.O., \& Talaat, N.M. (2009). Motivations of Young Volunteers in Special Events. Tourismos: An International Multidisciplinary Journal of Tourism, 4(1), 145-152.

Plavša, J., Romelić, J., \& Vuksanović, D.L. (2009). Active Holiday in Mt. Zlatibor County. Turizam, 13(1), 28-44.
Radivojević, Z., \& Paunović, D. (2011). Importance of households for the development of event tourism in the municipality Lučani. Journal of the Geographical Institute "Jovan Cvijić", 61(3), 109-118. DOI:10.2298/ IJGI1103109R.

Republički zavod za statistiku Republike Srbije. (2013, July 6). Turistički promet u Republici Srbiji. Retrieved August 2, 2013, from http://webrzs.stat.gov.rs/WebSite/Public/PageView.aspx?pKey=182 (in Serbian)

Službeni glasnik Republike Srbije. (2006). Strategija razvoja turizma Republike Srbije. Službeni glasnik Republike Srbije, 91. (in Serbian)

Stamenković, I., Pivac, T., Blešić, I., \& Besermenji, S. (2013). Festival Branding - Case Study: The Dragačevo Trumpet Festival in Guča. Turizam, 17(1), 29-37.

Štetić, S., \& Šimičević, D. (2008). How to develop sustainable tourism in rural destinations in Serbia. Glasnik Srpskog geografskog drustva, 88(4), 19-28. DOI:10.2298/ GSGD0804019S.

Stojkov, B., \& Nikolov, A. (2011). The Cultural Potentials and Constraints for Cross-border Co-operation in Tourism-the Case of Balkans. Regional Cooperation in Tourism Development (pp. 47-61). Belgrade: Belgrade Chamber of Commerce.

UN Joint Programme "Sustainable Tourism for Rural Development”. (2011). Master Plan for Sustainable Rural Tourism Development in Serbia. Belgrade: UN Joint Programme "Sustainable Tourism for Rural Development".

United Nations Environment Programme. (2011). Towards a green economy: Pathways to Sustainable Development and Poverty Eradication. Nairobi, Kenya: UNEP.

Unković, S. (2011). Effect of Economic Crisis on Global Tourism. Cooperation in Tourism Development-Sustainable Development as a Precondition for Competitiveness in Tourism (pp. 87-99). Belgrade: Belgrade Chamber of Commerce.

Vasilevska, L. (2010). Rural Tourism as a part of multifuntional agriculture-possibilities and limitations. Regional development in the field of tourism development (pp. 35-46). Belgrade: Belgrade Chamber of Commerce.

Vasilevska, L. (2011). Sustainable Development of Rural Tourism in the Function of Spatial Development of Rural Areas. Cooperation in Tourism DevelopmentSustainable Development as Precondition for Competitiveness in Tourism (pp. 131-139). Belgrade: Belgrade Chamber of Commerce.

Voigt, C., Brown, G., \& Howat, G. (2011). Wellness tourists: in search of transformation. Tourism Review, 66(1/2), 16-30.

World Tourism Organization and European Travel Commision. (2005). City Tourism \& Culture. Madrid: World Tourism Organization. 
World Tourism Organization and European Travel Commission. (2011). Handbook on Tourism Product Development. Madrid: World Tourism Organization (UNWTO); Brussels : European Travel Commission (ETC).

World Tourism Organization. (2011). Policy and Practice for Global Tourism. Madrid: Word Tourism Organization (UNWTO).

World Tourism Organization. (2011). Tourism Towards 2030 Global Overview. Madrid: World Tourism Organization (UNWTO).
Y. Gee, C., \& Fayos-Sola, E. (1997). International Tourism: A Global Perspective. Madrid: World Tourism Organization (UNWTO).

Zrilić, D. (2011). Strategic Directions in Development of Rural Tourism in Serbia. Regional Cooperation in Tourism Development (pp. 69-76). Belgrade: Belgrade Chamber of Commerce.

\section{PREDLOG ZA MARKETINŠKU KAMPANJU SRPSKIH TURISTIČKIH DESTINACIJA}

\section{Rezime:}

Srbija je geografski locirana u Evropi, i zbog toga je suočena sa oštrom konkurencijom iz drugih evropskih destinacija, ali i drugih svetskih destinacija. Kako bi se sagledalo moderno konkurentsko okruženje, identifikovani su trendovi na globalnom, regionalnom i lokalnom nivou. Podaci iz analize srpskog turističkog tržišta u letnjoj sezoni iskorišćeni su kako bi se kreirali profili turista prema 4 emitivna regiona (domaći-Srbija; Zapadni Balkan-Slovenija, Hrvatska, Bosna, Crna Gora, Kosovo i Makedonija; Centralno-istočna Evropa-Austrija, Češka, Slovačka, Poljska, Mađarska, Rumunija; Zapadna Evropa i ostatak sveta), za 5 glavnih srpskih destinacija (Beograd, Novi Sad, Niš, Zlatibor, Kopaonik), kao i za 7 vrsta turista na osnovu nihove primarne motivacije za putovanje (zadovoljstvo, zabava, priroda, kultura, sport i avantura, zdravlje i posao). Na bazi turističkih profila kreirani su zasebni marketinški scenariji za svaki od tržišnih segmenata.

\section{Ključne reči:}

turistička marketinška kampanja, profili turista, marketing destinacije, istraživanje tržišta, segmentacija tržišta.

Received: August 21st, 2013.

Correction: September 22nd, 2013.

Accepted:September 23rd, 2013. 